\title{
INVALIDITY OF LAST WILL AND TESTAMENT UNDER THE LAW OF THE RUSSIA
}

\author{
I. Kostyuk ${ }^{1}$ \\ DOI: http://doi.org/10.15350/L_26/8/03
}

\section{Abstract}

In paper legal issues bound with invalidity of last will and testament, grounds for its invalidation, correlation to general regulations for invalidity of civil transactions in the Russian Federation legal system are considered. action.

Keywords: invalidity of last will and testament, unilateral contract, nullity

In its legal nature last will and testament is a unilateral contract not demanding coordination of will of those persons, whom last will and testament is addressed. As other contracts, last will and testament can be held as invalid or to be such in presence of lack of legal competence, will, form and content of last will and testament. Depending on grounds for invalidation, last will and testament can be held invalid by court or without such acknowledgement. In the former case voidable contract is meant, the article 1131 of the Russian Federation Civil Code sets, however, a rule of impossibility to dispute last will and testament before opening of inheritance that in its turn comes after death of testator. In the latter case null transaction is meant that doesn't require acknowledgment of invalidation through legal proceedings, but requires enforcement of implications of invalidity.

Under likeness of legal regulation of last will and testament invalidity facts with other contracts with blemish, this legal institute has some peculiarities. There are special norms of civil law that regulate invalidity of last will and testament in the V section of the $3^{\text {rd }}$ part of the Russian Federation Civil Code. Special (specific) norms subject to immediate application in relation to general norms on contract invalidity $(§ 2$, chapter 9 , subsection IV section I "General regulations" of civil law).

The institute of contract invalidity is aimed first of all at regulation of relations formalized by contracts - two-way or multilateral transactions - and last will and testament is a unilateral act and, as it was already mentioned above, it is impossible to dispute last will and testament before opening of inheritance that means presence of another fact - death of testator. This circumstance complicates application of consequences of invalidity of last will and testament in virtue of its nullity. Thus, parties of transaction (testator and heritor(s)) generally when applying consequences of null transaction in the absence of null action must acknowledge the fact of transaction invalidity that is fast impossible under some objective and subjective causes. [1, 104].

Nonobservance of written form of transaction (sub-paragraph 2 item I article 1124 of the Russian Federation Civil Code). Last will and testament must be

1 Irina Kostyuk, PhD legal Sciences, associate professor, Kazan (Volga) federal university, Naberezhnye Chelny institute (branch), Russia.

orcid.org/0000-0001-7824-7773. 
in written form. It is a binding norm in contrast to provisions of 162 article of the Russian Federation Civil Code that covers general rule in case of nonobservance of written form and causes invalidity of last will and testament.

Nonobservance of qualified written form of transaction (sub-paragraph 2 item I article 1124 of the Russian Federation Civil Code).

Last will and testament must be certified by notary. Drawing up of will and testament in simple writing form is envisaged as an exception to the rule and only in virtue of emergency when a citizen's life is menaced and he has not a possibility to observe established order. Such last will and testament lose its validity if it will be not properly drawn up within a month after emergency.

Last will and testament may be made, but on condition of certifying this fact by court upon demand of the parties concerned and on condition of such demand will be declared before expiry date of acceptance of inheritance.

Right for performing notarial acts can be granted by law to local government and consular institutions. The article 1127 of the Russian Federation Civil Code establishes a list of last will and testament amounted to notarized and a list of persons who have a right (responsibility) to take such actions. Among these are head physicians and doctors on duty of hospitals and nursing homes for the elderly, physically challenged individuals; captains that are at sea flying the flag of the Russian Federation, commanders of exploratory, Arctic/Antarctic expeditions; commanding officers of military units situated in areas where there are no notaries and so on.

Last will and testament must be signed by testator's own hand and in some cases written by testator (item 3 article 1125 of the Russian Federation Civil Code, item 2 article 1126 of the Russian Federation Civil Code, paragraph 2 item 1 article 1129 of the Russian Federation Civil Code). In the absence of a possibility to sign at one's own hand by virtue of corporal, physiological defects or illiteracy last and testament can be signed by another person, but at request of (with consent of) testator and before a notary. Under these circumstances it is necessary to state causes of such signature and personal data of a signer. Last will and testament can be drawn up together with notary according to oral information provided by testator, red by testator aloud before a notary for understanding of content and specification of wordings $[2,232]$. valid.

When failing to abide by above-named rules, last will and testament is in-

Absence of witnesses or their non-compliance with requirements in accordance with item 3 article 1124 of the Russian Federation Civil Code.

A number of articles of the Russian Federation Civil Code envisage compulsory presence of witnesses when certifying last will and testament under penalty of nullity. Item 3 article 1126 - closed last will and testament in a stuck down envelope handed over by testator to notary before two witnesses that sign the envelope; article 1127 - last will and testament amounted to notarized is signed by testator before certifying official and witness; last will and testament made in emergency is acknowledged as such if it is signed by testator in presence of two witnesses. Moreover, witness can be present at wish of testator under usual circumstances of making last will and testament certified by notary that will be compulsory matter of procedure for notary. 
Item 2 article 1124 of the Russian Federation Civil Code establishes a list of persons who cannot be witnesses when making last will and testament: notary or a person in charge of certifying, inheritors, legally incapable or illiterate citizens etc. Last will and testament made before above-mentioned witnesses can be acknowledged as invalid that is this circumstance must be litigated.

Last will and testament can be acknowledged as invalid both in whole and in part; restoration of invalid transaction according to general principles applicable to last will and testament is not always possible. At the same time, presence of small errors, slips of the pen, errors in preparation procedure in last will and testament doesn't mean that it is invalid if court found that it doesn't affect the understanding of will expression of testator.

One more significant fact is that invalidity of last will and testament doesn't diminish rights of persons stated there to inherit under the law or another valid last will and testament.

\section{References:}

Marukhno V.M. Nedeistvitelnost zaveshchaniya s porokami formy / Vlast zakona. Izdatelstvo: Nauchno-issledovatelskiy institut aktualnykh problem sovremennogo prava. Krasnodar. - 2015. - S. 103-109.

Chulova YU.S. Nedeistvitelnost zaveshchaniya / Ekonomika, sotsiologiya, pravo. Izdatelstvo: Nauchno-informatsionnyy izdatelskiy tsentr "Institut strategicheskikh issledovaniy", Moskva. - 2015. - S. 231-233.

Regulations and case materials:

[1] Grazhdanskiy kodeks Rossiyskoy Fedratsii (chast pervaya): Federalnyy zakon ot 30.11.1994 № 51-FZ [red. ot 03.07.2016] //Sobranie zakonodatelstva RF. 05.12.1994. - № 32 .

[2] Grazhdanskiy kodeks Rossiyskoy Fedratsii (chast tretya): Federalnyy zakon ot 26.11.2001 № 146- FZ [red. ot 03.07.2016] // Rossiyskaya gazeta. - № 233. 28.11.2001.

[3] Konsulskiy ustav Rossiyskoy Federatsii: Federalnyy zakon ot 05.07.2010 №154- FZ [red. ot 21.07.2014]//Sobranie zakonodatelstva RF. - 12.07.2010. - № 28, st. 3554.

[4] Ob obshchikh printsipakh organizatsii mestnogo samoupravleniya v Rossiyskoy Federatsii: Federalnyy zakon ot 06.10 .2003 № 131-FZ [red. ot 03.07.2016] // Sobranie zakonodatelstva RF. - 06.10.2003. - № 40, st. 3822.

[5] Osnovy zakonodatelstva Rossiyskoy Federatsii o notariate: Postanovlenie VS RF ot 11.02.1993 № 4463-1. (utv. VS RF 11.02.1993 N 4462-1) [red. ot 03.07.2016] // Rossiyskaya gazeta. - № 49. - 13.03.1993.

[6] sudebnoy praktike po delam o nasledovanii: Postanovlenie Plenuma Verkhovnogo Suda RF ot 29.05.2012 № 9 // Rossiyskaya gazeta. - № 127. - 06.06.2012

[7] priznanii zaveshchaniya nedeistvitelnym: Opredelenie Verkhovnogo Suda RF ot 04.02.2014 № 19-КГ13-12 // Opublikovano ne bylo. Istochnik:http://www.consultant.ru/cons/cgi/online.cgi?req=doc;base=ARB; $=378724 \# 0$

[8] Ob ustanovlenii fakta soversheniya zaveshchaniya $v$ chrezvychainykh obstoyatelstvakh, priznanii zaveshchaniya deistvitelnym i vosstanovlenii sroka dlya prinyatiya nasledstva: Opredelenie Verkhovnogo Suda RF ot 09.12.2014 № 18KG14-150 // Opublikovano ne bylo. Istochnik: http://www.consultant.ru/cons/cgi/online.cgi?req=doc;base=ARB; $n=414793 \# 0$. 